\title{
HELMINTHS OF EUROPEAN SMELT OSMERUS EPERLANUS (LINNAEUS, 1758) IN LAKE HAŃCZA AND THE VISTULA LAGOON, WITH SPECIAL REGARD TO THEIR ZOONOTIC THREATS
}

\author{
Janina DZIEKoŃSKA-RYNKO ${ }^{1}$, Katarzyna MIERZEJEWSKA ${ }^{2 *}$, Katarzyna KUBIAK ${ }^{3}$, \\ Martyna RYDZEWSKA ${ }^{1}$ and Piotr HLIWA ${ }^{4}$ \\ ${ }^{1}$ Department of Zoology, Faculty of Biology and Biotechnology; ${ }^{2}$ Department of Fish \\ Biology and Pisciculture, Faculty of Environmental Sciences; ${ }^{3}$ Department of Medical \\ Biology, Faculty of Health Sciences; ${ }^{4}$ Department of Ichthyology, Faculty of \\ Environmental Sciences, University of Warmia and Mazury in Olsztyn, \\ Oczapowskiego str. 2, 10-719 Olsztyn, Poland
}

(Received 27 September 2017; accepted 6 November 2017)

Reports published in recent years on the increased risk in the Baltic Sea of fish infection with larvae of nematodes potentially pathogenic to humans have prompted a study of European smelt Osmerus eperlanus with respect to the presence of these parasites in the Vistula Lagoon. Additionally, samples of this fish from Lake Hańcza were comparatively considered. The body cavity, the surface of internal organs, the alimentary tract and the swimbladder of fish from two environmentally different water bodies were taken into account in the analysis. Only the tapeworm Proteocephalus longicollis was found in the alimentary tract of the fish from Lake Hańcza. Depending on the period of study, the prevalence ranged from $60 \%$ to $100 \%$, and the mean intensity from 11.5 to 42.0 . The helminth fauna of smelt from the Vistula Lagoon was more diverse: Cystidicola farionis occurred with a prevalence from 25.9 to $75.0 \%$ and a mean intensity of infection from 2.7 to $66.0 \%$, Proteocephalus longicollis and cystacanths of Corynosoma with a prevalence ranging in different years from 12.0 to $44.0 \%$ and from 14.8 to $50.0 \%$, respectively. Zoonotic parasites, such as nematode larvae of the Anisakidae family (Contracaecum sp., Anisakis simplex), occurred in the intestine with a prevalence of $31 \%, 72 \%$ and $22 \%$ in consecutive years of the study.

Key words: Smelt, parasites, zoonotic threats, Baltic Sea

In Poland, there are large populations of European smelt Osmerus eperlanus in the Szczecin Lagoon, the Gulf of Gdańsk and the Vistula Lagoon; moreover, this fish species occurs in 65 lakes in the north of Poland (Brylińska, 2000), including a quite large population in Lake Hańcza (Kozłowski et al., 2008).

Smelt prefers cold, well-aerated waters, and is very sensitive to eutrophication and pollution. Until the second year of its life, it feeds exclusively on *Corresponding author; E-mail: katarzyna.mierzejewska@uwm.edu.pl;
Phone: 0048-696450407 
plankton, then turns to predatory feeding, largely based on cannibalism (Brylińska, 2000; Kuhn et al., 2013). Due to its diverse ecology (sedentary, anadromous and adfluvial populations), wide tolerance range to salinity (from ocean to freshwaters) and opportunistic feeding, the fish often become an intermediate or paratenic host of many parasites, typical of both fresh- and seawaters (Wiśniewski and Piasecki, 2001; Rolbiecki, 2003; Kuhn et al., 2013; Głoćko, 2016).

Populations of European smelt in the Baltic and North Seas and in coastal lakes are known to be infected with larvae of Anisakidae nematodes, such as Anisakis simplex, Pseudoterranova decipiens, Contracaecum osculatum, Hysterothylacium aduncum (Möller and Klatt, 1990; Obiekezie et al., 1992; Wiśniewski and Piasecki, 2001; Karl, 2006; Kuhn et al., 2013; Głoćko, 2016). The life cycle of these nematodes is associated with salt water, where the planktonic and benthic crustaceans are the first intermediate host, while whales (for A. simplex) and seals (for $P$. decipiens and $C$. osculatum) act as definitive host. According to many parasitologists, a rapid increase in the seal population in the Baltic has a significant effect on increasing infection of fish with these nematodes (Buchmann and Kania, 2012; Haarder et al., 2014; Mehrdana et al., 2014; Nadolna and Podolska, 2014; Lunneryd et al., 2015; Strøm et al., 2015). Fish are now included in a group of paratenic hosts (Klimpel and Palm, 2011), in which larvae settle in the body cavity after piercing through the intestinal wall. Larvae of Contracaecum and Anisakis spp. are usually found in the peri-intestinal adipose tissue, visceral peritoneum, liver, intestinal wall and gonadal surface, whereas larvae of $P$. decipiens are found predominantly in the muscles. Humans may become accidentally infected with live larvae of Anisakis, Contracaecum or Pseudoterranova spp. by eating raw or improperly cooked fish meat (Buchmann and Mehrdana, 2016). The disease caused by these nematodes is called anisakiosis. It was recorded in many countries during the past two decades and its increased incidence has been attributed to the increased number of fish infected and to the growing popularity of oriental cuisine. Cases of anisakiosis caused by larvae of Contracaecum spp. have been described in patients who consumed fish caught in the Baltic Sea (Möller and Schröder, 1987) and in Japanese (Nagasawa, 2012) and Australian waters (Shamsi and Butcher, 2011). Animals infected in the laboratory (rats, rabbits) exhibited similar histopathological changes as in infections with Anisakis and Pseudoterranova (Fagerholm, 1988; Strøm et al., 2015). Cases of allergy have been described following the consumption of fish meat containing thermoresistant allergens produced by nematode larvae of the Anisakidae family (Audicana et al., 2002; Carballeda-Sangiao et al., 2014).

The aim of this study was to determine the occurrence of helminths in the body cavity, on the surface of internal organs and in the alimentary tract and swimbladder of European smelt from the Vistula Lagoon and in Lake Hańcza, and indicate those which are hazardous to humans. 


\section{Materials and methods}

\section{Research area}

The Vistula Lagoon $\left(54^{\circ} 27^{\prime} 00^{\prime \prime} \mathrm{N}, 19^{\circ} 45^{\prime} 00^{\prime \prime} \mathrm{E}\right)$ is a part of the Gulf of Gdańsk, separated by the Vistula Spit from the Baltic Sea, with which it is connected by the Strait of Piława. In stormy weather, seawater flowing into the Lagoon increases its salinity, which is not uniform and decreases from 5.5 to $2.2 \%$ with increasing distance from the strait.

Lake Hańcza $\left(54^{\circ} 16^{\prime} 18.1^{\prime \prime} \mathrm{N}, 22^{\circ} 48^{\prime} 51.5^{\prime \prime} \mathrm{E}\right)$, situated in the Suwałki Lake District, is the deepest (maximal depth: $108.5 \mathrm{~m}$ ) and one of the cleanest freshwater bodies in Poland. It has a deep and properly-aerated hypolimnion, which creates favourable conditions for the growth and development of species that prefer cold water and high oxygen concentrations.

\section{Parasitological investigation}

All the fish examined were caught by commercial fishing gears. The parasitological studies were conducted on European smelt Osmerus eperlanus caught in Lake Hańcza in 2013 and 2014 (total: 58 individuals) and in the Vistula Lagoon in 2015, 2016 and 2017 (total: 68 individuals) (Table 1). Freshly-dead fish were examined in the laboratory on the day of sampling. The body cavity and surface of internal organs were viewed under stereomicroscope (SMZ-U DIA STAND, Nikon), the alimentary tract and the swimbladder were cut lengthwise, decanted with physiological saline $(0.65 \% \mathrm{NaCl})$ and examined either with a compound light microscope (ECLIPSE E600W, Nikon) or a stereomicroscope. Parasites were identified directly or after being preserved by fixation in $70 \%$ ethanol as described by Grabda (1971), Moravec (1994), Pojmańska (1991) and Grabda-Kazubska and Okulewicz (2005).

\section{Results}

The tapeworm Proteocephalus longicollis was found in the intestine of smelt from Lake Hańcza. The prevalence was 100\% in March 2013 and April 2014, while the mean intensity of infection ranged from 25.5 to 42.0 in that period. In November $2014,60.0 \%$ of fish were infected with a mean intensity of 11.5 (Table 1). No other parasites were found, either on the internal organs or inside the intestine and swimbladder of smelt from Lake Hańcza.

The list of helminths in smelt caught in the Vistula Lagoon was more diverse. The nematode Cystidicola farionis was found in the swimbladder. The highest level of infection (prevalence 75\%, mean intensity $66.0 \pm 73.3$ ) was recorded in 2015, and larvae definitely dominated (47.5 per fish on average) (Table 1). 


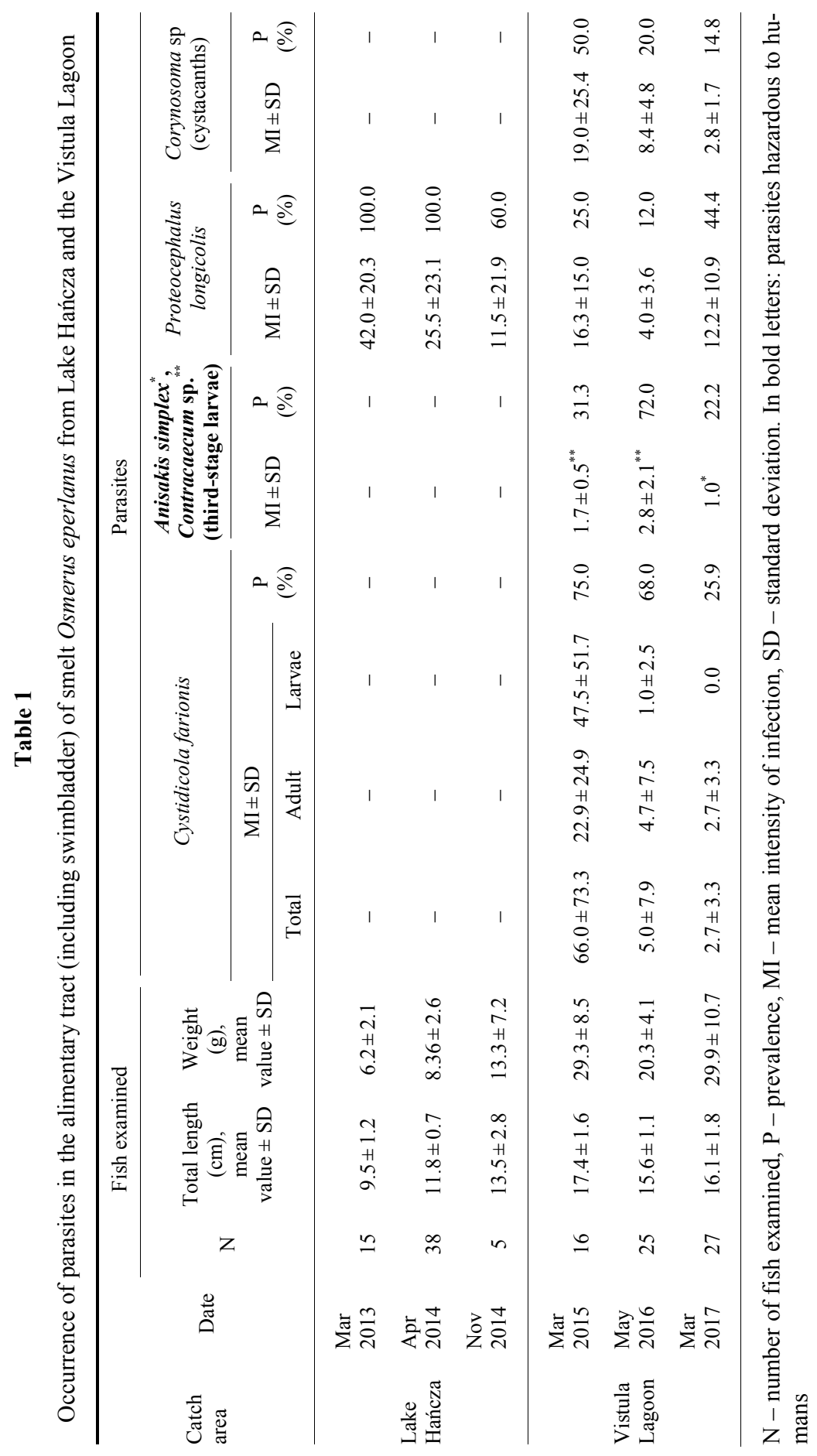


The infection indices were lower in 2016 and 2017: prevalence $68.0 \%$ and $25.9 \%$, respectively; mean intensity $5.0 \pm 7.9$ and $2.7 \pm 3.3$. The tapeworm Proteocephalus longicollis and cystacanths of Corynosoma acanthocephalans were found in the intestinal lumen. The prevalence of the tapeworm in consecutive years was $25.0 \%, 12.0 \%$ and $44.0 \%$ with mean intensities of $16.3,4.0$ and 12.2 , respectively. Cystacanths were found in $50.0 \%, 20.0 \%$ and $14.8 \%$ of the fish, depending on the study period (Table 1). Encysted 3rd stage larvae of Contracaecum sp. were found in the intestinal wall (Fig. 1) and A. simplex in the intestinal lumen. All detected larvae were alive, and some larvae of Contracaecum sp. left the capsule during microscopic observations (Fig. 1b). The prevalence in consecutive years was $31.0 \%, 72.0 \%$ and $22.0 \%$ with mean intensities of infection of 1.7, 2.8 and 1.0, respectively (Table 1).

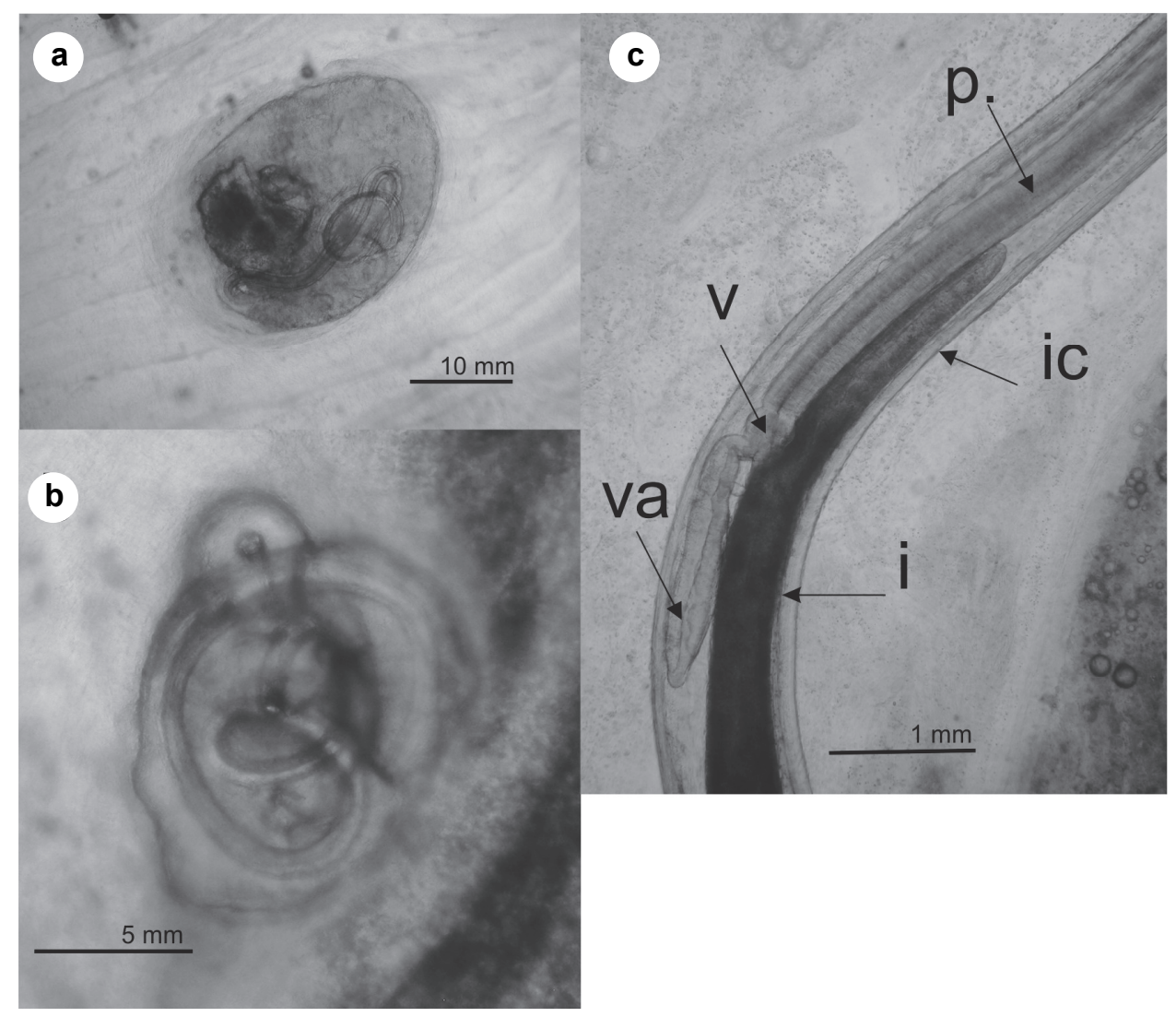

Fig. 1. Third-stage larvae of Contracaecum sp. in European smelt from the Vistula Lagoon; a) larvae encapsulated in the intestinal wall; b) larval excapsulation; d) free larvae, the middle part of body; p) pharynx; v) ventriculus; va) ventricular appendix; i) intestine; ic) intestinal caecum 


\section{Discussion}

The tapeworm $P$. longicollis occurred in the majority of fish in Lake Hańcza and in the Vistula Lagoon (Table 1). It is a common parasite of the alimentary tract of smelt, which occurs especially in Osmeridae and also in salmonid fish (Coregonidae, Salmonidae) in the whole Palearctic region (Scholz et al., 2007; Głoćko, 2016). Planktonic crustaceans (numerous Copepoda species of the Diaptomidae and Cyclopidae families) are intermediate hosts of this tapeworm (Scholz, 1999). A number of them occur in Lake Hańcza, including the Siberian species Eurytemora gracilis (Tunowski, 2008), which is also the potential first host of Proteocephalus genera (Scholz, 1999). Different planktivorous fish are the definitive hosts of $P$. longicollis (Pojmańska, 1991; Pojmańska et al., 2007). The tapeworm occurs in smelt in fresh, brackish and sea waters. Quite high infection indices were determined for smelt in Lake Dąbie and in two lakes in the Drawsko Lake District - Żerdno and Pile, with prevalences of $36.6 \%, 34.7 \%$ and $86.0 \%$, and maximum intensities of infection of 146, 16 and 84 parasites per fish, respectively (Wiśniewski and Piasecki, 2001; Głoćko, 2016). In anadromous populations in Ireland, Doherty and McCarthy (2004) observed the highest infection level in June (prevalence 59.3\%, intensity 42.0). In the study conducted by Anikieva (1998) on fish from Lakes Ladoga and Onega the infection was much lower (prevalence 3.3\% and 13.3\%, respectively), while in the Gulf of Bothnia the prevalence reached $30 \%$.

Considering the above data, the infection level of smelt in Lake Hańcza was relatively high (Table 1). This can be attributed to the favourable characteristics of water in the lake studied, such as temperature, aeration or the absence of pollutants, which may support copepod populations (Hanzelová and Gerdeaux, 2003). The life cycle of $P$. longicollis can also include paratenic hosts, which are reservoirs of the parasite and a source of infection for larger predatory fish (Scholz, 1999; Moravec, 2001). Such a role in Lake Baikal is played by fish of the Cottidae family (Rusinek and Pronin, 1991). Lake Hańcza is a specific ecosystem; with fish species typical of cold waters of the north and mountain streams, including the burbot Lota lota and bullheads Cottus gobio and C. poecilopus (Wziątek and Poczyczyński, 2008). The European bullhead is regarded as the paratenic host for this tapeworm in Europe (Moravec, 2001). Juvenile and adult tapeworms of the genus Proteocephallus can also be transmitted horizontally through the cannibalism of fish hosts. In view of the limited population density of zooplankton (Tunowski, 2008), typical of low-trophy water bodies, the high level of smelt infection in Lake Hańcza can be attributed to acquiring the parasite by cannibalism and to the occurrence of the paratenic hosts mentioned above, which - although not prey to smelt - can support the parasite population in the water body studied. 
Composition of the helminth fauna found in fish caught in the Vistula Lagoon was more diverse and the level of infection with $P$. longicollis was considerably lower than in Lake Hańcza (Table 1). This could be attributed to the composition of crustacean plankton: species mentioned as the first intermediate hosts of the tapeworm were rare and not abundant in the Lagoon (Paturej et al., 2012); in addition, paratenic hosts have not been detected to date.

The highly pathogenic nematode Cystidicola farionis was frequent in smelt from the Lagoon. It is a common parasite of salmonid fish, located in the swimbladder. Its prevalence depends on the age of fish, the feeding strategy and the season of the year (Valtonen, 1978; Giaever et al., 1991; Knudsen et al., 2002). Amphipoda are intermediate hosts of this nematode. Since younger fish usually prey in the profundic and pelagic zones, where these crustaceans do not occur, the intensity of infection in younger fish is usually much lower than in older ones, like those examined in the Lagoon (mean length ranging from 15.6 to $17.4 \mathrm{~cm}$ ) (Table 1). The nematode was first found in the smelt in Lake Dąbie (prevalence 61.0\%, mean intensity 196.0) (Wiśniewski and Piasecki, 2001). Smelt as open-bladder fish (Physoclisti) is susceptible to parasite invasion throughout its life. A high level of infection, attributable to the long duration of nematode life and the lack of the host's immunity to reinvasions, may cause anaemia and swimbladder inflammations, which can hinder the filling of that organ and, as a consequence, impair its hydrostatic and respiratory functions. In extreme cases, this can lead to the destruction of the swimbladder walls and to the death of fish (Lankester and Smith, 1980; Willers et al., 1991). Infected fish swim more slowly and their escape capability is limited, which makes them vulnerable to predator pressure (Sprengel and Lüchtenberg, 1991). An increased mortality of fish as a result of infection with the nematode was observed especially in the autumn, when amphipods (intermediate host) availability as a food item for fish was increased (Giaever et al., 1991; Knudsen et al., 2002). Cusack and Cone (1986) emphasised the role of $C$. farionis as a transmitter of many bacterial diseases. There are no reports in the literature on the pathogenicity of this nematode to other animals or to humans.

This study was the first to find encysted third-stage larvae of Contracaecum sp. and third-stage larvae of Anisakis simplex in smelt from the Vistula Lagoon. Larvae of these nematodes were found in other fish species in the Lagoon, such as pikeperch Sander lucioperca, lumpfish Cyclopterus lumpus and Atlantic herring Clupea herengus (Rolbiecki and Rokicki, 2000, 2002, 2008; Rolbiecki, 2003). These nematodes occur in the sea environment, where intermediate (Euphausiacea) and definitive (Cetacea) hosts occur, but there have been increasingly frequent reports on their occurrence in fish in brackish waters and freshwaters in coastal lakes (Rolbiecki, 2006, 2010).

Third-stage larvae of Anisakis simplex and Contracaecum sp. were first found in Poland in the round goby Neogobius melanostomus (Rolbiecki, 2006) 
and in the perch in coastal lakes (Lake Żarnowieckie and Lake Raduńskie Dolne) (Rolbiecki, 2010). In recent years, a distinct increase in infection with larvae of Contracaecum has been observed in fish in the Baltic Sea, especially in the cod (Gadus morhua) (Haarder et al., 2014; Mehrdana et al., 2014; Nadolna and Podolska, 2014; Lunneryd et al., 2015). There have been fewer reports on the occurrence of these larvae in other fish species (Unger et al., 2014). The majority of authors have attributed this phenomenon to the constant increase in the number of seals in the Baltic Sea (Haarder et al., 2014). Harbour seal Phoca vitulina, ringed seal Phoca hispida and grey seal Halichoerus grypus are common along the Polish coast, especially in the Gulf of Gdańsk, the Gulf of Puck, in the Vistula estuary and near the Hel Peninsula (on the side of the open sea) (HELCOM, 2015).

With an increase in the number of potential definitive hosts, one can expect an increase in the emission of nematode eggs to the environment and, in consequence, an increase in the level of fish infections. Occurrence of larvae of Contracaecum in smelt from the Vistula Lagoon (Table 1) can be connected with the nearby presence of seals. Apart from sea mammals, fish-eating birds also contribute significantly to the propagation of nematodes of the Anisakidae family. Parasitological examinations of cormorants from various colonies have shown that, along with larvae of Contracaecum rudolphii (prevalence 100\%), larvae of A. simplex have often been found in these birds (Kanarek and Rolbiecki, 2006; Stocka et al., 2017). The largest colony of cormorants in this part of Europe, in Kąty Rybackie on the Vistula Spit, may significantly affect the fish parasite assemblage in the Vistula Lagoon. According to Rolbiecki (2010), the presence of larvae of A. simplex and Contracaecum sp. (typical of salt waters) in fish in Lake Żarnowieckie and Raduńskie Duże is most probably caused by the river link of these lakes with the Baltic Sea and by the fact that cormorants and other fisheating birds prey on Baltic Sea waters.

Parasitological studies of smelt caught in the estuaries of the Elbe and in the North Sea have shown that the prevalence of $P$. decipiens often exceeds $40 \%$ (Möller and Klatt, 1990; Obiekezie et al., 1992; Karl, 2006; Kuhn et al., 2013). They have usually been found in muscles, where they settle after a fish dies, abandoning the intestinal walls and the body cavity. In the present study, $P$. decipiens was not found but larvae of Anisakis spp. and Contracaecum sp. potentially pathogenic for humans were present in the intestinal wall of freshly dead fish. According to the authors cited above, this is a serious zoonotic threat, because baked or fried fish, without gutting, are served in many restaurants in Germany as local delicacies. A similar issue can also be faced by consumers in Poland, because restaurants more and more often tend to serve whole cooked smelt. 


\section{References}

Anikieva, L. V. (1998): Cestodes of the genus Proteocephalus (Cestoda: Proteocephalidea) from the European smelt Osmerus eperlanus. Parasitologia 32, 134-140.

Audicana, M. T., Ansotegui, I. J., Corres, L. F. and Kennedy, M. W. (2002): Anisakis simpex: dangerous-dead and alive? Trends Parasitol. 18, 20-24.

Brylińska, M. (2000): Freshwater fishes of Poland. 3rd edition. Warszawa, PWN [in Polish]. 521 pp.

Buchmann, K. and Kania, P. (2012): Emerging Pseudoterranova decipiens (Krabbe, 1878) problems in Baltic cod, Gadus morhua L., associated with grey seal colonization of spawning grounds. J. Fish Dis. 35, 861-866.

Buchmann, K. and Mehrdana, F. (2016): Effects of anisakid nematodes Anisakis simplex (s.1.), Pseudoterranova decipiens (s.1.) and Contracaecum osculatum (s.1.) on fish and consumer health. FAWPAR 4, 13-12.

Carballeda-Sangiao, N., Olivares, F., Rodriguez-Mahillo, A. I., Careche, M., Tejada, M., Moneo, I. and González-Muñoz, M. (2014): Identification of autoclave-resistant Anisakis simplex allergens. J. Food Protect. 4, 605-609.

Cusack, R. and Cone, D. K. (1986): A review of parasites as vectors of viral and bacterial diseases of fish. J. Fish Dis. 9, 167-171.

Doherty, D. and McCarthy, T. K. (2004): The ecology and conservation of European smelt (Osmerus eperlanus L.) from Waterford estuary in southeastern Ireland. Biol. Environ. Proc. Royal Irish Academy 104B, 125-130.

Fagerholm, H. P. (1988): Incubation in rats of a nematodal larva from cod to establish its specific identity: Contracaecum osculatum (Rudolphi). Parasitol. Res. 75, 57-63.

Giaever, A. A., Klemetsen, A. and Halvorsen, O. (1991): Infection of Cystidicola farionis Fischer (Nematoda: Spiruroidea) in the swimbladder of arctic charr, Salvelinus alpinus (L.), from Takvatn, North Norway. Nord. J. Fresh. Res. 66, 63-71.

Głoćko, M. (2016): Parasitic Metazoa in smelt (Osmerus eperlanus L.) from selected lakes of the Drawa Watershed Area. Ann. Parasitol. 62, 106.

Grabda, J. (1971): Catalogue of Polish Parasite Fauna. Part II. Parasites of Cyclostomata and Fish. Warszawa-Wrocław, PWN [in Polish]. 304 pp.

Grabda-Kazubska, B. and Okulewicz, A. (2005): Fish parasites of Poland (identification key) Nematoda [in Polish]. Warszawa, Polish Parasitological Society, Warszava. 168 pp.

Haarder, S., Kania, P. W., Galatius, A. and Buchmann, K. (2014): Increased Contracaecum osculatum infection in Baltic cod (Gadus morhua) livers (1982-2012) associated with increasing grey seal (Halichoerus gryphus) populations. J. Wildl. Dis. 50, 537-543.

Hanzelová, V. and Gerdeaux, D. (2003): Seasonal occurrence of the tapeworm Proteocephalus longicolis and its transmission from copepod intermediate host to fish. Parasitol. Res. 91, 130-136.

HELCOM (Baltic Marine Environment Protection Commission - Helsinki Commission) Core Indicator Report (2015): Population trends and abundance of seals. Online. [http://www.helcom.fi/Core\%20Indicators/Population\%20trends\%20and\%20abundance\%20 of $\% 20$ seals-HELCOM\%20core\%20indicator\%20report\%202015-extended\%20version.pdf]

Kanarek, G. and Rolbiecki, L. (2006): Third-stage larvae of Anisakis simplex (Rudolphi, 1809) in the Great Cormorant [Phalacrocorax carbo sinensins (Blumenbach, 1798)] from the Vistula Lagoon, Poland. Oceanol. Hydrobiol. Stud. 35, 23-28.

Karl, H. (2006): Composition and nematodes in smelt (Osmerus eperlanus L.). Inf. Fischereiforsch. 53, 65-70.

Klimpel, S. and Palm, H. W. (2011): Anisakid nematode (Ascaridoidea) life cycles and distribution: increasing zoonotic potential in the time of climate change? In: Mehlhorn, H. (ed.) Progress in Parasitology, Parasitology Research Monographs 2, Springer-Verlag, BerlinHeidelberg. pp. 201-222. 
Knudsen, R., Amundsen, P. A. and Klemetsen, A. (2002): Parasite-induced host mortality: indirect evidence from a long-term study. Environ. Biol. Fishes 64, 257-265.

Kozłowski, J., Kozłowski, K., Poczyczyński, P., Szmyt, M. and Stańczak, K. (2008): Planctivorous fish. In: Kozłowski, J., Poczyczyński, P. and Zdanowski, B. (eds) Environment and the Fish Fauna of Lake Hańcza [in Polish]. Wydawnictwo Instytutu Rybactwa Śródlądowego, Olsztyn, Poland. pp. 131-146.

Kuhn, T., Benninghoff, T., Karl, H., Landry, T. and Klimpel, S. (2013): Sealworm Pseudoterranova decipiens s.s. infection of European smelt Osmerus eperlanus in German coastal waters: ecological implications. Dis. Aquat. Org. 102, 217-224.

Lankester, M. W. and Smith, J. D. (1980): Host specificity and distribution of the swim-bladder nematodes Cystidicola farionis Fischer, 1978 and C. cristivomeri White, 1941 (Habronematoidea) in salmonid fishes of Ontario. Can. J. Zool. 58, 1298-1305.

Lunneryd, S., Bostrom, M. K. and Aspholm, P. E. (2015): Sealworm (Pseudoterranova decipiens) infection in grey seals (Halichoerus grypus), cod (Gadus morhua) and shorthorn sculpin (Myoxocephalus scorpius) in Baltic Sea. Parasitol. Res. 114, 257-264.

Mehrdana, F., Bahlool, Q., Skov, J., Marana, M. H., Sindberg, D., Mundeling, M., Overgaard, B. C., Korbut, R., Strøm, S. B., Kania, P. W. and Buchmann, K. (2014): Occurrence of zoonotic nematodes Pseudoterranova decipiens, Contracaecum osculatum and Anisakis simplex in cod (Gadus morhua) from Baltic Sea. Vet. Parasitol. 205, 581-587.

Möller, H. and Klatt, S. (1990): Smelt as host of the sealworm (Pseudoterranova decipiens) in the Elbe estuary. Can. Bull. Fish. Aquat. Sci. 222, 129-138.

Möller, H. and Schröder, S. (1987): Neue Aspekte der Anisakiasis in Deutschland [in German]. Arch. Lebensmittelhyg. 38, 123-128.

Moravec, F. (1994): Parasitic nematodes of freshwater fishes of Europe. Academia and Kluwer Academic Publishers, Praha and Dordrecht, Boston, London. pp. 360-366.

Moravec, F. (2001): Common sculpin Cottus gobio as a natural paratenic host of Proteocephalus longicollis (Cestoda: Proteocephalidae), a parasite of salmonids, in Europe. Dis. Aquat. Org. 45, 155-158.

Nadolna, K. and Podolska, M. (2014): Anisakid larvae in the liver of cod (Gadus morhua L.) from the Southern Baltic Sea. J. Helminthol. 88, 237-246.

Nagasawa, K. (2012): The biology of Contracaecum osculatum sensu lato and C. osculatum A (Nematoda: Anisakidae) in Japanese waters: a review. Biosphere Sci. 51, 61-69.

Obiekezie, A. I., Lick, R., Kerstan, S. and Möller, H. (1992): Larval nematodes in stomach wall granuloses of smelt Osmerus eperlanus from the German North Sea coast. Dis. Aquat. Org. 12, 177-183.

Paturej, E., Gutkowska, A. and Mierzejewska, J. (2012): Long-term quantitative and qualitative changes in the zooplankton community of the Vistula Lagoon. J. Coastal Res. 30, 1-7.

Pojmańska, T. (1991): Parasites in Polish Fish (Identification Key). Tapeworms - Cestoda [in Polish]. Institute of Parasitology of the Polish Academy of Sciences, Warszawa. $135 \mathrm{pp}$.

Pojmańska, T., Niewiadomska, K. and Okulewicz, A. (2007): Parasitic Helminths of Poland Species, Hosts, Grey Areas [in Polish]. Polskie Towarzystwo Parazytologiczne, Warszawa. $360 \mathrm{pp}$.

Rolbiecki, L. (2003): Diversity of the parasite fauna of cyprinid (Cyprinidae) and percid (Percidae) fishes in the Vistula Lagoon, Poland. Wiad. Parazytol. 49, 125-164.

Rolbiecki, L. (2006): Parasites of the round goby, Neogobius melanostomus (Pallas, 1811), an invasive species in the Polish fauna of the Vistula Lagoon ecosystem. Oceanologia 48, 545-561.

Rolbiecki, L. (2010): Diversity of metazoan parasite communities in selected fish species from water basins with different degrees of anthropogenic stress. Oceanol. Hydrobiol. Stud. 39, Suppl. 2, 3-150.

Rolbiecki, L. and Rokicki, J. (2000): The occurrence of the nematodes Anisakis simplex pathogenic to man in pike-perch from Vistula Lagoon, Poland. Wiad. Parazytol. 46, 397-402. 
Rolbiecki, L. and Rokicki, J. (2002): III-stage of Anisakis simplex (Rudolphi, 1809) (Nematoda: Anisakidae) larvae in herring caught in autumn from the Polish part of the Vistula Lagoon. Acta Sci. Pol., Piscaria 1, 105-110.

Rolbiecki, L. and Rokicki, J. (2008): Helminths of the lumpsucker (Cyclopterus lumpus) from the Gulf of Gdańsk and Vistula Lagoon (Poland). Oceanol. Hydrobiol. Stud. 37, 355-359.

Rusinek, O. T. and Pronin, N. M. (1991): Proteocephalus tymalli and P. exiguous. In: Dynamics of Animal Infections by Worm. Buryat Scientific Center, Ulan-Ude.

Scholz, T. (1999): Life cycles of species of Proteocephalus parasites of fishes in the Palearctic region: A review. J. Helminthol. 73, 1-9.

Scholz, T., Hanzelová, V., Škeřiková, A., Shimazu, T. and Rolbiecki, L. (2007): An annotated list of species of the Proteocephalus Weinland, 1858 aggregate sensu de Chambrier et al. (2004) (Cestoda: Proteocephalidea), parasites of fishes in the Palaearctic Region, their phylogenetic relationships and a key to their identification. Syst. Parasitol. 67, 139-156.

Shamsi, S. and Butcher, A. R. (2011): First report of human anisakidosis in Australia. Med. J. Aust. 194, 199-200.

Sprengel, G. and Lüchtenberg, L. (1991): Infection by endoparasites reduces maximum swimming speed of European smelt Osmerus eperlanus and European eel Anguilla anguilla. Dis. Aquat. Org. 11, 31-35.

Stocka, I., Dziekońska-Rynko, J., Mierzejewska, K., Stańczak, K. and Wziątek, B. (2017): Occurrence of nematodes in the alimentary tract of great cormorants [Phalacrocorax carbo (Linnaeus, 1758)] in colonies located in the upper and lower Vistula River. Oceanol. Hydrobiol. Stud. 46, 168-174.

Strøm, S. B., Haarder, S., Korbut, R., Mejer, H., Thamsborg, S. M., Kania, P. W. and Buchmann, K. (2015): Third-stage nematode larvae of Contracaecum osculatum from Baltic cod ( $G a$ dus morhua) elicit eosinophilic granulomatous reactions when penetrating the stomach mucosa of pigs. Parasitol. Res. 114, 1217-1220.

Tunowski, J. (2008): Pelagic zooplankton of Lake Hańcza. In: Kozłowski, J., Poczyczyński, P. and Zdanowski, B. (eds) Environment and the Fish Fauna of Lake Hańcza [in Polish]. Wydawnictwo Instytutu Rybactwa Śródlądowego, Olsztyn, Poland. pp. 103-114.

Unger, P., Klimpel, S., Lang, T. and Palm, H. W. (2014): Metazoan parasites from herring (Clupea harengus L.) as biological indicators in the Baltic Sea. Acta Parasitol. 59, 518-528.

Valtonen, E. T. (1978): Cystidicola farionis as a swimbladder parasite of the whitefish in the Bothnian Bay. J. Fish Biol. 13, 557-561.

Willers, W. B., Dubielzig, R. R. and Miller, L. (1991): Histopathology of the swimbladder of the cisco due to the presence of the nematode Cystidicola farionis Fisher. J. Aquat. Anim. Health 3, 130-133.

Wiśniewski, G. and Piasecki, W. (2001): Parasite fauna of smelt, Osmerus eperlanus (L.) from Lake Dąbie, northwestern Poland. Wiad. Parazytol. 47, 52.

Wziątek, B. and Poczyczyński, P. (2008): Protected fish species. In: Kozłowski, J., Poczyczyński, P. and Zdanowski, B. (eds) Environment and the Fish Fauna of Lake Hańcza [in Polish]. Wydawnictwo Instytutu Rybactwa Śródlądowego, Olsztyn, Poland. pp. 125-129. 